\title{
Contract Farming and Profitability: Evidence from Rice Crop in the Central Mekong Delta, Vietnam
}

\author{
Tran Quoc Nhan ${ }^{1,2}$, Tomoyuki Yutaka ${ }^{3}$ \\ ${ }^{1}$ United Graduate School of Agricultural Sciences, Kagoshima University, Japan \\ ${ }^{2}$ College of Rural Development, Can Tho University, Vietnam \\ ${ }^{3}$ Faculty of Agriculture, Kagoshima University, Japan
}

\begin{abstract}
This study aims at investigating profitability of rice contract farming in Vietnam's Mekong delta. We used data from a farm-household survey comprising of 70 contract and 96 noncontract respondents, and apply the Student's t-test and ordinary least square regression model for data analysis. We found that farmers with larger rice plantations are unlikely to engage in contract farming, and that market outlets and output price for contract growers tend to be ensured compared with noncontract ones. The findings reveal that contract farming has a significantly positive impact on rice-farming profitability in terms of average return and average rate of return on variable cost when controlling for observable characteristics of household and farm. The results suggest that contract farming may enable rice farmers to raise their rice income as well as household income. The policy implication may be that contract farming may not be feasible for all rice farmers and rice business firms.
\end{abstract}

\section{Keywords}

Contract farming, return, average rate of return, rice, Mekong delta.

Nhan, T. Q. and Yutaka, T. (2019) "Contract Farming and Profitability: Evidence from Rice Crop in the Central Mekong Delta, Vietnam", AGRIS on-line Papers in Economics and Informatics, Vol. 11, No. 1, pp. 83-91. ISSN 1804-1930. DOI 10.7160/aol.2019.110109.

\section{Introduction}

Contract farming $(\mathrm{CF})$ is considered an institutional measure to assure the quantity and quality of raw materials for exporters, processors, distributors, and supermarkets (Reardon et al., 2009; Swinnen and Maertens, 2007). In addition, CF can solve major constraints for smallholder farmers such as access to inputs, financial problems, technical capacity, information and price, and market outlets at harvest (Barrett et al., 2012; Miyata et al., 2009; Swinnen and Maertens, 2007). Many studies show that contract farming improve largely farm productivity and households income or welfare such as those by Girma and Gardebroek (2015), Naryananan, (2014), Dedehouanou et al. (2013), Cahyadi and Waibel (2013), Bellemare (2012), Maertens and Swinnen (2009), Miyata et al. (2009), Minten et al. (2009), and Bolwig et al. (2009). However, few studies have estimated the effect of $\mathrm{CF}$ on profitability $(\mathrm{Hu}, 2013)$. In addition, most CF studies have examined high-value products including industrial crops, horticulture, poultry, and dairy, but rarely staple foods (Maertens and Velde, 2017; Minot, 1986).
Contract farming used for agriculture and in particular for the rice sector has been encouraged and promoted by the Vietnamese government with attempts to improving farmmarket efficiency and farmers' income since its policy decision No. 80/2002/QD-TTg in 2002, which was amended by decision No. 62/2013/QD-TTg (2013). This policy provides incentives and support to those who engage in a contract scheme. Accordingly, farmers who participate in rice CF can take bank loans at a low interest rate and receive priority access to extension services. Meanwhile, the company that conducts rice $\mathrm{CF}$ also gains some benefits (e.g., preferential loans from commercial banks, priority approval of rice-export by the Vietnamese Ministry of Trade and Industry, and allocation of rice-export assigned by the Vietnam Food Association). Nevertheless, the uptake of CF in the rice sector is still limited in the Vietnamese Mekong delta (Nhan and Yutaka, 2017), which supplies annually more than 50\% of Vietnam's total rice production and $90 \%$ of its rice exports. Vietnam recently has become the world's third-largest rice exporter with $18 \%$ of international market share (FAO, 2016). 
Growing concern is also reflected in studies on $\mathrm{CF}$ conducted in Vietnam, such as those by Oanh et al. (2016), Wang et al. (2014), Saenger et al. (2013), and Tuan (2012); however, these authors mainly focused on industrial and vegetable crops and the dairy sector. Consequently, there is little evidence of any previous study on CF in the rice sector carried out in Vietnam, except for the study by Nhan and Yutaka (2017) that explored the constraints to the enforcement of rice $\mathrm{CF}$ in the Mekong delta and another study by Nhan et al. (2013) which examined the potential of contract farming on rice growers' income. At present, it is hard to find any existing study related to estimating impact of $\mathrm{CF}$ on profitability in rice farming although it has been strongly promoted for use in the delta since the 2000s (Can, 2014). Hence, we attempt to examine the profitability of rice cultivation with contract farming and to contribute significantly to rice production through $\mathrm{CF}$ in this region.

The remainder of this paper is organized as follows: the following section describes the farm household survey and data analysis methods used in this study. In Section 3, we present and discuss the results by focusing on a description of the $\mathrm{CF}$ scheme, socioeconomic characteristics for contract and noncontract farmers, and the profitability of rice crop with and without the contract scheme, and in the last section we summarize the findings and recommend policy implications.

\section{Materials and methods}

This study used primary data gathered from a household survey conducted in September 2017 in Can Tho city of the central Mekong delta where there are several companies specializing in rice processing and export. Data collection was focused on Co Do district, known as the largest rice-producing region of Can Tho city in terms of area and production, where $\mathrm{CF}$ is conducted by business firms and rice production is the most prevalent among other districts.

A structured questionnaire was used to collect household demographics, farm characteristics, assets, rice production and sales, production costs, inputs supply, income sources, and contractual details. The questionnaire was pre-tested to adjust the questions before conducting the household interviews. The practice of rice $\mathrm{CF}$ is still uncommon and a large number of rice growers in the study area do not engage in the contract scheme. Hence, the total sample numbered 166 rice growers, of which 96 farmers who had never participated in CF, while the remaining farmers who had participated.
Interviewees were selected randomly. Noncontract and contract farmers were identified from lists provided by the commune people's committee and from lists provided by contract firms, respectively. Noticeably, both groups of respondents reside and practice rice farming under the same geographic setting, which ensures that their natural conditions, traffic infrastructure, and cultural status are homogeneous. We also interviewed the two contract companies to gather information on their rice business.

A simple cost-return analysis was used to estimate the profitability of rice cultivation in the current study. The profitability was focused on not only estimating return and average rate of return on investment but also calculating variable cost and output price. We used the Student's t-test to test the mean differences for the two groups. Yet, the t-test does not allow controlling for other external factors that may substantially influence the outcomes. We thus employed Ordinary Least Square (OLS) regression models to estimate the different outcomes related to profitability performance such as average variable cost, selling price, mean return and average rate of return as functions of household and farm characteristics, and a dummy variable presenting participation in a $\mathrm{CF}$ scheme. The effect of participation in $\mathrm{CF}$ can be measured by the coefficients of variables for contract farming in the OLS regression model (Imbens, 2004; Wooldridge, 2002). This regression approach was applied in earlier studies by Maertens and Velde (2017), Krause and Machek (2018), Wang et al. (2014) and Miyata et al. (2009). The linear regression models can be written as follows:

$$
Y_{i}=\varphi_{i}+\alpha C_{i}^{\prime}+\beta X_{i}+\varepsilon_{i}
$$

Where $Y_{i}$ denotes the outcome variables as mentioned above. $C_{i}$ is a dummy variable for participation in contract farming. $X_{i}$ is a vector of continuous variables (age, education of household head, farming experience, household size, rice planted area) and dummy variables (social participation, owning boat, owning storage, sale after harvest and use of RTV variety). By including these observable factors, we can control for the observable differences between the two groups, which may influence the dependent variables (Maertens and Velde, 2017; Krause and Machek, 2018; Miyata et al., 2009). However, unobservable factors such as industrious and skillful characteristics of sampled farmers, which may influence the outcomes were not considered in the current study. 


\section{Results and discussion}

\section{Description of rice CF schemes}

As shown in Table 1, we shortly describe the major characteristics of the two contract companies operating in the area of the study. The investigation showed that the companies' sales are mostly in the export market and their procurement is mostly from contract farmers. With regard to contracting process, the company generally first approaches the local authority for its potential contracting locations. Second, after identifying the location with support from the local authority, the company holds an orientation meeting for rice farmers who wish to participate in the contract scheme. After the meeting, the farmers make decision whether to participate in $\mathrm{CF}$ or not. More importantly, the company accepts all farmers registering, even if their rice plantation is small. Lastly, the company and individual farmers sign a written contract prior to rice cultivation that commits the company to buy the entire output and transport it to the company's facilities. The contract specifies the rice variety, area planted, anticipated output volume, output quality, price mechanism and agrochemical use. The company provides the seed variety to all their contract farmers, but it may not provide pesticide and fertilizer.

The results in Table 1 showed that about $11 \%$ of contract farmers receive fertilizer and pesticide from the company. It also delivers technical training to the contract growers and offers market price plus a premium. For contract farmers, they also commit to selling their output to the company as well as following all contract terms agreed.

\section{Socioeconomic characteristics for contract and noncontract farmers}

The results of the Student's t-test for mean comparison of household and farm characteristics for contract and noncontract farmers are presented in Table 2. These results suggest that contract households are likely to have better human capital than noncontract ones. Indeed, contract households had more experience in rice farming and a larger household size compared with noncontract ones (significant at 0.05 ). The educational level of the heads of contract households seemed to be higher than those of noncontract ones, but the difference was not significant. However, it was observed that the head of contract households tended to be older than that of noncontract ones (significant at 0.05).

Farm scale in the sample was somewhat large, with a mean of 2.264 ha per household compared with the average farm size in the Mekong delta (1.4 ha), and the farm size for both groups appeared similar. However, noncontract farmers tended to hold slightly larger rice plantations compared with contract farmers (significant at 0.1 ). Evidence from the investigation suggested that the share of contract and noncontract farmers owning agricultural assets (storage, tractor, and combine harvester) was relatively small (less than 5\%). However, more than $50 \%$ of farmers in the study area owned a boat with a small loading capacity (transportation is mainly by river in the delta) and these farmers reported that their boat was mostly used for transporting farming inputs due to the underdeveloped road system that makes

\begin{tabular}{|c|c|c|}
\hline Variables & A enterprise & B enterprise \\
\hline Product & Rice & Rice \\
\hline \multicolumn{3}{|l|}{ Procurement $(\%)$} \\
\hline Contract farmers & 100 & 80 \\
\hline Spot market & & 20 \\
\hline \multicolumn{3}{|l|}{ Sales $(\%)$} \\
\hline Export market & 70 & 70 \\
\hline Domestic market & 30 & 30 \\
\hline+ Other export companies & 24 & 12 \\
\hline + Wholesalers and retailers & 6 & 18 \\
\hline \multicolumn{3}{|l|}{ Share of farmers receiving inputs (\%) } \\
\hline+ Seed & 100 & 100 \\
\hline+ Fertilizer and pesticides & 0 & 11.4 \\
\hline Determination of price & Market price plus premium & Market price plus premium \\
\hline Year of starting contract with farmers & 2013 & 2012 \\
\hline
\end{tabular}




\begin{tabular}{lcccc}
\hline Variable & $\begin{array}{c}\text { All sample } \\
(\mathrm{n}=166)\end{array}$ & $\begin{array}{c}\text { Noncontract } \\
\text { farmers } \\
(\mathrm{n}=96)\end{array}$ & $\begin{array}{c}\text { Contract } \\
\text { farmers } \\
(\mathrm{n}=70)\end{array}$ & $\begin{array}{c}\text { Mean } \\
\text { difference }\end{array}$ \\
\hline Age of head (years) & 50.12 & 48.44 & 52.43 & $3.991^{* *}$ \\
Farming experience of head (years) & 25.25 & 23.69 & 27.40 & $3.713^{* *}$ \\
Education of head (years of schooling) & 6.34 & 6.06 & 6.71 & 0.652 \\
Household size (persons) & 4.59 & 4.39 & 4.87 & $0.486^{* *}$ \\
Farm size (ha) & 2.26 & 2.43 & 2.04 & -0.381 \\
Rice planted area (ha) & 2.19 & 2.39 & 1.91 & $-0.475^{*}$ \\
Owning boat (yes=1, otherwise=0) & 0.58 & 0.58 & 0.57 & -0.012 \\
Owning storage (yes=1, otherwise=0) & 0.04 & 0.06 & 0.01 & -0.048 \\
Owning tractor (yes=1, otherwise=0) & 0.04 & 0.05 & 0.03 & -0.024 \\
Owning combine harvester $(\mathrm{yes}=1$, otherwise=0) & 0.01 & 0.01 & 0.01 & 0.004 \\
Share of rice income $(\%)$ & 90.36 & 91.78 & 88.5 & -3.281 \\
Social participation (yes=1, otherwise=0) & 0.23 & 0.18 & 0.30 & $0.123^{*}$ \\
Distance to nearest dryers (km) & 2.01 & 2.06 & 1.93 & -0.128 \\
\hline
\end{tabular}

Note: $*$ and $* *$ denote significances at 0.1 and 0.05 levels, respectively

Source: Authors' estimates from the survey

Table 2: Household and farm characteristics for contract and non-contract rice farmer.

farms inaccessible by truck. The average distance to the nearest drying facilities among the surveyed households was $2 \mathrm{~km}$. This distance did not differ as they reside under the same geographic setting. The possible implication of these results is that physical capital for contract and noncontract farmers is seemingly similar.

The major source of income for both contract and noncontract growers is from rice production, which generates approximately $90 \%$ of their total income. This implies that the financial source for surveyed households is likely to depend on their rice-farming performance. Participation in farmer-based organizations (e.g., an agricultural cooperative, cooperative group, or extension club) may play an important role in enhancing farmers' social capital and providing more opportunities for farmers to access extension services and expand their public relations. The share of sampled farmers engaging in such organizations was relatively low; however, contract farmers participated in these organizations at a higher rate than noncontract ones, which implies that farmers who are members of farmer-based organizations are more likely to engage in CF schemes than other farmers.

\section{Rice-farming profitability with and without a contract scheme}

The results of a t-test mean comparison for outcome indicators between contract and noncontract farming models are presented in Table 3 . We did not include the fixed costs of crop sprayers, tractors, harvesters, and land since they are long-term assets applicable to other farming activities and few farmers own a tractor and harvester. Hence, we mainly used variable costs to calculate costs and return.

The average variable cost for contract farmers was $3.8 \%$ lower than that for noncontract ones (significant at 0.1). Accordingly, the costs of irrigation and postharvest (e.g., drying and transport costs) for the contract group were likely to be lower as compared with the other group. Yet the share of irrigation and postharvest costs was relatively small, accounting for $2.6 \%$ and $0.5 \%$ of the total cost, respectively. A possible explanation for the differences in these costs is that some noncontract farmers dried and stored their output after harvest, whereas the output of most contract farmers was collected by the contract company right after harvested. As discussed earlier, contract farmers seem to have better human capital and smaller rice plantations, which may result in better water management. However, other variable cost items for contract and noncontract farmers did not differ tremendously. Specifically, the costs of soil preparation and rice seed appeared to be, on average, $5.4 \%$ and $10.3 \%$ of total cost, respectively, and the costs for pesticides and fertilizers were displayed as the highest and the second largest shares, constituting 30\% and $25 \%$ of the total cost structure, respectively. In addition, harvest cost accounted for $12 \%$ of total cost (hiring a combine harvester instead of a manual harvest as these machines are widely used in the Mekong delta). The total labor costs for both farming methods appeared similar, 


\begin{tabular}{lcccc}
\hline Variable & $\begin{array}{c}\text { All sample } \\
(\mathrm{n}=166)\end{array}$ & $\begin{array}{c}\text { Noncontract } \\
\text { farmers } \\
(\mathrm{n}=96)\end{array}$ & $\begin{array}{c}\text { Contract } \\
\text { farmers } \\
(\mathrm{n}=70)\end{array}$ & $\begin{array}{c}\text { Mean } \\
\text { difference }\end{array}$ \\
\hline (1) Average variable costs $(\mathrm{VNDa} / \mathrm{kg})$ & 2,479 & 2,519 & 2,423 & $-95.49 *$ \\
$\quad$ Land preparation cost & 136 & 134 & 140 & 5.97 \\
Seed cost & 256 & 259 & 251 & -7.56 \\
Pesticides cost & 743 & 756 & 723 & -33.57 \\
Fertilizers cost & 628 & 635 & 620 & -14.74 \\
Combine harvester hired cost & 284 & 284 & 285 & 1.37 \\
Hired labor cost & 202 & 209 & 193 & -16.50 \\
Family labor cost & 153 & 154 & 152 & -1.93 \\
Irrigation cost & 65 & 69 & 60 & $-9.32 *$ \\
Postharvest cost & 12 & 20 & 0 & $-20.03 * * *$ \\
(2) Unit selling price $(\mathrm{VND} / \mathrm{kg})$ & 5,220 & 5,202 & 5,244 & 42.02 \\
(3) Unit return $(\mathrm{VND} / \mathrm{kg})(2)-(1)$ & 2,733 & 2,683 & 2,821 & $137.70^{*}$ \\
(4) Average rate of return $(3) /(1)$ & 1.14 & 1.09 & 1.22 & $0.13 * *$ \\
\hline
\end{tabular}

Note: $*, * *$ and $* * *$ denote significances at $0.1,0.05$ and 0.01 levels, respectively

a1 USD is taken as 22,500 VND

Source: Authors' estimates from the survey.

Table 3: Profitability of rice farming with and without a contract scheme.

attributing an average $14.3 \%$ of total variable cost.

As a second outcome, the output price received by contract and noncontract farmers did not differ even though the contract companies committed to offering an average of $200 \mathrm{VND} / \mathrm{kg}$ higher than the normal market price. The explanation for this may be that some noncontract growers selling their paddy a number of days after harvest might prompt an increase in price by around $1,212 \mathrm{VND} / \mathrm{kg}$, equivalent to $24 \%$ of average selling price (Table 4).

The third outcome is that the average unit return achieved by contract farmers was 5.1\% higher than for noncontract ones (significant at 0.1 ). The possible reason for this is that the average variable cost for contract farmers was significantly smaller than other group.

The last outcome indicator - average rate of return or return on variable cost investment value for contract and noncontract farming models - was 1.22 and 1.09, respectively, which suggests that contract farmers tended to obtain approximately $12 \%$ greater return than noncontract farmers (significant at 0.05). This result implies that the contract and noncontract farming models are able to generate a return of 1.22 million VND and 1.09 million $\mathrm{VND}$, respectively, for every 1 million VND invested in a rice crop, suggesting that rice production through a contract scheme is more likely to be profitable on variable costs in the study area.

\section{Estimated effect of contract farming on profitability of rice cultivation}

As earlier discussion, some remarkable differences exist in observable covariates, including rice plantation size and human capital indicators, across the samples. It was assumed that these characteristics might have an implicit impact on the profitability of both contract and noncontract growers. Therefore, these variables and a $\mathrm{CF}$ variable (dummy) should be simultaneously included in the regression model to estimate the effect of a contract scheme on rice-farming profitability. We found that CF had no impact on the average variable cost (Table 4), whereas previous studies indicated that contract farming results in an increase of inputs costs (Maertens and Velde, 2017; Miyata et al., 2009). This result is also not in line with the above t-test analysis. However, the regression results showed that participation in a contract scheme had a dramatically positive effect on the outputselling price. The coefficient on the contract variable suggests that $\mathrm{CF}$ raises the selling price by $160 \mathrm{VND} / \mathrm{kg}$, equivalent to $3 \%$ of output price (significant at 0.01 ), while the t-test result showed no significant difference. The possible reason for this may be that the quality of output produced by contract farmers under the supervision of the company could be better than other farmers did. This result is in line with the findings 
of Maertens and Velde (2017), Girma and Gardebroek (2015), and Miyata et al. (2009). Similar to t-test results, we found that participation in $\mathrm{CF}$ greatly increases mean return and average rate of return on variable costs, significant at 0.05 and 0.1 , respectively. The implication of the results from the regression may be that $\mathrm{CF}$ has a positive effect on profitability of rice growers in the study area. This finding is also consistent with earlier studies by Mishra, et al. (2018), Hu (2013) and Bolwig et al. (2009).

Table 4 also reports the full regression results for different outcome indicators including average variable cost, selling price, average return and average rate of return. We now explain briefly the major factors affecting these dependent variables. First, the households with older heads obtained a lower selling price but the size of this effect was relatively small. Second, it found that households with heads having higher education result in a small decrease in production cost, since farmers with higher education seem to have better management in their rice cultivation. As a result, this factor sharply raised mean return and average rate of return. Third, farmers with longer experience in rice farming were likely to gain higher profitability. Fourth, larger rice plantation remarkably increased the output-selling price, likely so because of the fact that farmers who sell a larger output volume receive a higher price because purchasers can reduce transportation cost for collecting paddy at many small individual farms. This variable also led to obtaining slightly larger return. Fifth, membership in farmer-based organizations could lead to a slight decrease in variable cost, which results in higher profitability because farmers who are members of the farmer organization were likely to have better access to extension services resulting in better management for their crop (Dang, 2017). Sixth, boat ownership might cause the largest decrease in total cost, which may be associated with to a large reduction in transporting cost for inputs. As a result, this factor contributes to a large increase in profitability. Seventh, storage ownership could result in an increase in selling price; likely explained by the higher quality of output. Eighth, selling output after harvest might lead to a remarkable increase in total cost but this factor also greatly increases the selling price, making a greater unit return. This likely relates to storage cost and small supply of rice in the market after peak harvest period. Finally, using RTV variety could make to a positive significant impact on selling price owing to the higher quality of RVT variety (fragrant rice variety).

\begin{tabular}{|c|c|c|c|c|}
\hline \multirow{2}{*}{ Explanatory variables } & \multicolumn{4}{|c|}{ Dependent variables (Coefficient) } \\
\hline & Average variable cost & Selling price & Mean return & Average rate of return \\
\hline Contract farming (dummy) & -10.624 & $160.450 * * *$ & $171.069 * *$ & $0.140 *$ \\
\hline Age of head (years) & -0.759 & $-4.256 * *$ & -3.498 & -0.002 \\
\hline Education of head (years of schooling) & $-19.045 * *$ & 3.721 & $22.767 * *$ & $0.019 * *$ \\
\hline Farming experience of head (years) & -4.878 & 3.176 & $8.054 *$ & $0.006^{*}$ \\
\hline Household size (persons) & 7.514 & -2.198 & -9.712 & -0.011 \\
\hline Rice planted area (ha) & -8.623 & $25.213 * * *$ & $33.836^{*}$ & 0.021 \\
\hline Social participation (dummy) & $-103.368 *$ & 52.718 & $156.087 * *$ & $0.128 * *$ \\
\hline Owning boat (dummy) & $-189.592 * * *$ & -40.074 & $149.518 * *$ & $0.160 * * *$ \\
\hline Owning storage (dummy) & -109.383 & $224.200 * * *$ & $333.584 *$ & 0.161 \\
\hline Selling after harvest (dummy) & $630.747 * * *$ & $1,212.000 * * *$ & $580.857 * * *$ & -0.081 \\
\hline Applying RTV variety (dummy) & 131.114 & $287.240 * * *$ & 156.123 & -0.016 \\
\hline Constant & $2,834.000 * * *$ & $5,112.120 * * *$ & $2,278.000 * * *$ & $0.804 * * *$ \\
\hline F-value & 5.672 & 54.330 & 7.978 & 3.768 \\
\hline Probability value $>$ F & 0.000 & 0.000 & 0.000 & 0.000 \\
\hline Adjusted $\mathrm{R}^{2}$ & 0.240 & 0.780 & 0.320 & 0.160 \\
\hline Number of observation & 166 & 166 & 166 & 166 \\
\hline
\end{tabular}

Note: $* * *$ and $* * *$ denote significances at $0.1,0.05$ and 0.01 levels, respectively

Source: Authors' estimates from the survey 


\section{Conclusion}

The study investigates the major differences between contract and noncontract rice growers for various characteristics. Contract farming households were found to have better human and social capital, but they were likely to own remarkably less rice land area than noncontract ones. The outlet and price of output for the contract group are more likely to be ensured compared with the noncontract one. Interestingly, some noncontract farmers who sold their output some days after harvest could receive a remarkably higher price. As the main objective of the study, that is to estimate profitability of rice cultivation under a contract scheme, it found that CF had a significantly positive impact on the profitability of rice crop in terms of return and average rate of return. This suggests that the contract scheme may increase both rice and household incomes for rice growers since the sampled households' income is mainly derived from rice cultivation. Although CF may be highly effective for increasing small-farm income, it is only applicable in certain circumstances (Miyata et al., 2009). Expanding $\mathrm{CF}$ in the rice sector is likely an effective measure to reach the Vietnamese government's target for improving market efficiency (farmgate price) and rice growers' income.

As in earlier studies and based on the results from this study, it is convinced that contract farming is more likely to be of benefit to small farmers and favor

Corresponding authors

Ph.D. Candidate and Lecturer Tran Quoc Nhan

College of Rural Development, Can Tho University, 270000, Vietnam

Phone:+84-293-351 1111,E-mail: tqnhan@ctu.edu.vn

\section{References}

[1] Barrett, C. B., Bachke, M., Bellemare, M. F., Michelson, H. C., Narayanan, S. and Walker, T. F. (2012) "Smallholder participation in contract farming: Comparative evidence from five countries", World Development, Vol. 40, No. 4, pp. 715-730. ISSN 0305-750X. DOI 10.1016/j.worlddev.2011.09.006.

[2] Bellemare, M. F. (2012) "As you sow, so shall you reap: the welfare impacts of contract farming", World Development, Vol. 40, No. 7, pp. 1418-1434. ISSN 0305-750X. DOI 10.1016/j.worlddev.2011.12.008.

[3] Bolwig, S. Gibbon, P. and Jones, S. (2009) "The economics of smallholder organic contract farming in tropical Africa", World Development, Vol. 37, No. 6, pp. 1094-1104. ISSN 0305-750X. DOI 10.1016/j.worlddev.2008.09.012.

[4] Cahyadi, E. R., and Waibel, H. (2013) "Is contract farming in the Indonesian oil palm industry pro-poor?", Journal of Southeast Asian Economies, Vol. 30, No. 1, pp. 62-69. ISSN 2339-5095.

[5] Can, N. D. (2014) "Understanding linking together four houses in rice production and commerce: a case study of An Giang province, Vietnam and lesson learnt from Chiba prefecture, Japan”, No. 486, JETRO, Chiba, Japan. oriented-export commodities. The findings current study imply that contract farming to stable crops and rice sector particularly but several previous studies indicate that successful contract-farming schemes with such crops are not The possible policy implication from the study is firms cannot provide certain inputs (e.g., seed, agrochemicals) and technical guidance to their financial resources. Some farmers, particularly large-scale farmers, are likely not to engage outlet choices that can sometimes enable them to achieve a higher selling price.

of contract farming on rice-farming profitability in Vietnam's Mekong delta, our estimation of farm and household and bias selection that were not addressed in this study. Hence, there should be by other econometric approaches. Furthermore, investigation with larger sample sizes in different locations and with various types of contracts should be carried out. method by OLS regression analysis still has some 
[6] Dang, N. H. (2017) "Profitability and profit efficiency of rice farming in Tra Vinh province, Vietnam", Review of Integrative Business and Economics Research, Vol. 6, No. SI 1, pp. 191-201. ISSN 2304-1013.

[7] Dedehouanou, S. F. A., Swinnen, J. and Maertens, M. (2013) "Does contracting make farmers happy? Evidence from Senegal", The Review of Income and Wealth, Vol. 59, No. S1, pp. 138-160. ISSN 1475-4991. DOI 10.1111/roiw.12041.

[8] FAO (Food and Agriculture Organization of the United Nations) (2016) "Rice Market Monitor", Rome, Italy.

[9] Girma, J. and Gardebroek, C. (2015) "The impact of contract on organic honey producers' income in southwestern Ethiopia", Forest Policy and Economics, Vol. 50, pp. 259-268. ISSN 1389-9341. DOI 10.1016/j.forpol.2014.08.001.

[10] Hu, W. Y. (2013) "Effects of contract farming on the U.S. crop farmers' average income", Agricultural Economics-Czech, Vol. 59, No. 5, pp. 195-201. ISSN 1805-9295.

[11] Imbens, G. W. (2004) "Nonparametric estimation of average treatment effects under exogeneity: a review", The Review of Economics and Statistics, Vol. 86, No. 1, pp. 4-29. ISSN 1530-9142.

[12] Krause, J. and Machek, O. (2018) "A comparative analysis of organic and conventional farmers in the Czech Republic", Agricultural Economics-Czech, Vol. 64, pp. 1-8. ISSN 1805-9295. DOI 10.17221/161/2016-AGRICECON.

[13] Maertens, M. and Swinnen, J. F. M. (2009) "Trade, standards and poverty: evidence from Senegal", World Development, Vol. 37, No. 1, pp. 61-178. ISSN 0305-750X. DOI 10.1016/j.worlddev.2008.04.006.

[14] Maertens, M. and Velde, K. V. (2017) "Contract farming in staple food chains: The case of rice in Benin", World Development, Vol. 95, pp. 73-87. ISSN 0305-750X. DOI 10.1016/j.worlddev.2017.02.011.

[15] Minot, N. (1986) "Contract farming and its effect on small farmers in less-developed countries", Working Paper No. 31, Michigan State University, the U.S.

[16] Minten, B., Randrianarison, L. and Swinnen, J. F. M. (2009) "Global retail chains and poor farmers: Evidence from Madagascar", World Development, Vol. 37, No. 11, pp. 1728-1741. ISSN 0305-750X. DOI 10.1016/j.worlddev.2008.08.024.

[17] Mishra, K. A., Kumar, A., Joshi, P. K. and D'Souza, A. (2018) "Impact of contract farming on yield, cost and profitability in low-value crop: evidence from a low-income country", The Australian Journal of Agricultural and Resource Economics, Vol. 62. No.4, pp. 1-19. ISSN 1467-8489. DOI 10.1111/1467-8489.12268.

[18] Miyata, S., Minot, N. and Hu, D. (2009) "Impact of contract farming on income: Linking small farmers, packers, and supermarkets in China", World Development, Vol. 37, Vol. 11, pp. 1781-1790. ISSN 0305-750X. DOI 10.1016/j.worlddev.2008.08.025.

[19] Naryananan, S. (2014) "Profits from participation in high-value agriculture: Evidence from heterogeneous benefits in contract farming schemes in Southern India”, Food Policy, Vol. 44, pp. 142-157. ISSN 0306-9192. DOI 10.1016/j.foodpol.2013.10.010.

[20] Nhan, T. Q. and Yutaka, T. (2017) "Current status and problems of rice contract farming enforcement in Mekong delta, Vietnam", Agricultural Marketing Journal of Japan, Vol. 26, No. 1, pp. 43-50.

[21] Nhan, T.Q., Takeuchi, I. and Hoang, D. V. (2013) "Rice contract farming - the potential key to improve rice growers' income: a farm level study in An Giang province", Vietnam Journal of Agricultural Sciences, Vol. 11, No. 7, pp. 1062-1072. ISSN 1859-0004.

[22] Oanh, L. T. K., Nga, B. T. and Lebailly, P. (2016) "Tea production between contract and noncontract farmers in Phu Tho province, Vietnam", Scholars Journal of Agriculture and Veterinary Sciences, Vol. 3, No. 2, pp. 117-122. ISSN 2348-1854. 
[23] Reardon, T., Barrett. C. B., Bergeue, J. A. and Swinnen, J. F. M. (2009) "Agrifood industry transformation and small farmers in developing countries", World Development, Vol. 37, No. 11, pp. 1717-1727. ISSN 0305-750X.

[24] Saenger, C., Qaim, M., Torero, M. and Viceisza, A. (2013) "Contract farming and smallholder incentives to produce high quality: experimental evidence from the Vietnamese dairy sector", Agricultural Economics, Vol. 44, No.3, pp. 297-308. ISSN 1574-0862. DOI 10.1111/agec.12012.

[25] Swinnen, J. F. M. and Maertens, M. (2007) "Globalization, privatization and vertical coordination in food value chains in developing and transition countries", Agricultural Economics, Vol. 37 , No. S1, pp. 89-102. ISSN 1574-0862. DOI 10.1111/j.1574-0862.2007.00237.x.

[26] Tuan, N. P. (2012) "Contract farming and its impact on income and livelihoods for small-scale farmers: case study in Vietnam”, Journal of Agribusiness and Rural Development, Vol. 4, No. 26, pp. 147-166. ISSN 1899-5772.

[27] Wang, H., Moustier, P. and Loc, N. T. T. (2014) "Economic impact of direct marketing and contracts: the case of safe vegetable chains in northern Vietnam", Food Policy, Vol. 47, pp. 13-23. ISSN 0306-9192. DOI 10.1016/j.foodpol.2014.04.001.

[28] Wooldridge, J. M. (2002) "Econometric analysis of cross section and panel data", the MIT Press. ISBN 0262232197. 